\section{(2) OPEN ACCESS}

\title{
Occupations and exposure events in acute and subacute irritant-induced asthma
}

\author{
Irmeli Lindström @ ( , Jussi Lantto, ${ }^{2,3}$ Kirsi Karvala, ${ }^{1,4}$ Satu Soini, ${ }^{5}$ Katriina Ylinen, ${ }^{6}$ \\ Hille Suojalehto, ${ }^{1}$ Katri Suuronen ${ }^{1}$
}

\begin{abstract}
- Additional material is published online only. To view please visit the journal online (http://dx.doi.org/10.1136/ oemed-2020-107323).
\end{abstract}

${ }^{1}$ Occupational Medicine, Finnish Institute of Occupational Health, Helsinki, Finland

${ }^{2}$ Pulmonary Medicine, Helsinki University Hospital Heart and Lung Center, Helsinki, Finland ${ }^{3}$ University of Helsinki Faculty of Medicine, Helsinki, Finland ${ }^{4}$ Varma Mutual Pension Insurance Company, Helsinki, Finland

${ }^{5}$ Occupational Health, Finnish Institute of Occupational Health, Oulu, Finland

${ }^{6}$ Work Environmental Laboratories, Finnish Institute of Occupational Health, Helsinki, Finland

\section{Correspondence to} Dr Irmeli Lindström,

Tyoterveyslaitos, Helsinki, Uusimaa, Finland: irmeli.lindstrom@ttl.fi

Received 18 December 2020 Revised 16 February 2021 Accepted 8 March 2021
D Check for updates

(c) Author(s) (or their employer(s)) 2021. Re-use permitted under CC BY-NC. No commercial re-use. See rights and permissions. Published by BMJ.

To cite: Lindström I, Lantto J, Karvala K, et al. Occup Environ Med Epub ahead of print: [please include Day Month Year].doi:10.1136/ oemed-2020-107323

\section{ABSTRACT}

Background Exposures leading to irritant-induced asthma (IIA) are poorly documented.

Methods We retrospectively screened the medical records of patients with IIA diagnosed in an occupational medicine clinic during 2000-2018. We classified the cases into acute (onset after single exposure) and subacute (onset after multiple exposures) IIA. We analysed in detail, occupations, causative agents and their air levels in the workplace, exposure events and the root causes of high exposure.

Results Altogether 69 patients were diagnosed with IIA, 30 with acute and 39 with subacute IIA. The most common occupational groups were industrial operators $(n=23,33 \%)$, metal and machinery workers $(n=16,11 \%)$ and construction workers $(n=12,8 \%)$ Among industrial operators significantly more cases had subacute IIA than acute IIA ( $p=0.002)$. Forty cases (57\%) were attributable to some type of corrosive acidic or alkaline chemical. Acute IIA followed accidents at work in different types of occupation, while subacute IIA was typical among industrial operators performing their normal work tasks under poor work hygiene conditions. The most common root cause was lack of information or false guidance in acute IIA $(n=11,36 \%)$ and neglect of workplace hygiene measures in subacute IIA ( $n=29$, 74\%).

Conclusions Accidents are the main causes of acute IIA, whereas subacute IIA can develop in normal work in risk trades with poor work hygiene. Airborne strong acids or bases seem to be the most important causative agents of acute and subacute IIA. The different risk profiles of acute and subacute IIA should be considered in the prevention and identification of the cases.

\section{INTRODUCTION}

Population-based studies have shown that accidental peak exposure to airborne irritant chemicals (later referred to as irritants) at work may cause a three-fold increase in the risk of asthma. ${ }^{12}$ Brooks et al first described how a single instance of highlevel exposure to irritative agents can cause asthma: reactive airways dysfunction syndrome or acute irritant-induced asthma (IIA). ${ }^{3} 4$ Later, repeated, not so high-level exposure to irritants has also been connected to asthma onset: not-so-sudden IIA or subacute IIA. ${ }^{5}$ Usually, IIA is work-related and accounts for $5 \%-18 \%$ of all occupational asthma cases. ${ }^{7}$ Irritants are less known than sensitisers as causative agents of occupational asthma, which hampers the recognition of IIA and the

\section{Key messages}

What is already known about this subject?

- Irritant-induced occupational asthma (IIA) is a rare disease, current knowledge on its causative agents is based on case reports and a few case series.

\section{What are the new findings?}

- The occupational exposure is evaluated elaborated in this large series of clinically verified cases of acute and subacute IIA.

- Operation and maintenance workers in metal, paper, chemical and food industry, construction workers, farmers and transport workers are at risk of IIA.

- Airborne substances classified as skin corrosive, such as acids and bases are potential causative agents of IIA.

- Acute IIA (onset after single exposure) followed accidents at work in many different types of occupation. The root cause of accidents was usually lack of information or poor guidance.

- Subacute IIA (onset after multiple exposures) was typical among industrial operators performing their normal work tasks under poor work hygiene conditions.

\section{How might this impact on policy or clinical} practice in the foreseeable future?

- Novel information about the risk occupations, agents and work tasks of acute and subacute IIA helps occupational safety authorities, workplaces and clinicians to direct preventive actions to relevant workers and to identify occupational asthma. The different risk profiles of acute and subacute IIA need to be considered.

understanding of the hazards of irritative agents at workplaces. The health impact of irritants is potentially high, because in IIA, persistent symptoms and abnormal lung function have still been reported years after diagnosis. ${ }^{8}$ Recently, the role of irritants as causes of adult-onset asthma in general has also been discussed. ${ }^{9}$

IIA is a rare disease and the current knowledge on its causative agents is based on case reports and a few case series. The cases have typically been connected to spills, accidental fires or the release of irritants resulting in high exposure to, for example, chlorine 
gas, di-isocyanates, acids, alkali, sulfuric gases, oxidising agents or different mixtures. ${ }^{3} 58$ 10-13 Many reports lack important information on the causative agents and the exposure leading to IIA, ${ }^{11}$ which hampers the risk assessment and prevention of this serious yet avoidable disease.

Here, we present a large case series of clinically verified occupational IIA. The purpose of our retrospective analysis of patients during the 2000s was to describe in detail risk occupations, work tasks and sectors; causative agents and their estimated air levels; and the root causes of exposure. Through this analysis, we hope to promote the identification and prevention of IIA.

\section{METHODS}

\section{Study population}

The Finnish Institute of Occupational Health (FIOH) is a tertiary outpatient clinic that confirms the diagnosis of most cases of occupational asthma in Finland (population of 5.5 million). We searched FIOH's patient register from 2000 to 2018 and included in our study all the cases with diagnosis number J68 and J45 (ICD-10) with relevant exposure to one or more irritants. We identified 69 patients with IIA diagnosis that fulfilled the criteria. ${ }^{56}$ The present study is based on the retrospective analysis of these 69 patients' medical records.

We coded the occupations using the International Standard Classification of Occupations ${ }^{14}$ and grouped them into two-digit levels.

\section{Diagnostic criteria}

The diagnostic criteria of IIA were (1) exposure to a high concentration of an irritant, (2) occurrence of asthma symptoms in a close temporal relationship to the exposure (usually $<24$ hours or after few days), (3) reversible obstruction or non-specific airway hyper-responsiveness in methacholine or histamine challenge, (4) persistence of symptoms $>3$ months, (5) no evidence of active asthma in adulthood before the exposure event and (6) no other pulmonary disorder that would explain the symptoms. $^{56}$

The participants were classified in two groups. The acute IIA group had only one high-level exposure event within 24 hours. The subacute IIA group had repeated exposure events to high levels of irritants during a period of more than 24 hours. ${ }^{56}$

\section{Information on exposure}

Our group, consisting of an occupational physician (KK), two pulmonologists (IL and JL) and an occupational toxicologist (KS), reviewed the patient files. We systematically evaluated the sources of information that had been used in the exposure assessment of each patient at the time of IIA diagnosis. In all cases, several types of exposure data were used (table 1).

We evaluated the exposure to irritants case by case, based on the following data: (1) causative agents and their safety data sheets (SDS) as regards physicochemical nature and hazard classifications, (2), information on the exposure event(s) and (3) results of workplace hygiene measurements and other workplace monitoring from the patients' own workplaces. The relevant measurements were selected according to the patients' work tasks, location in the workplace and the date of the measurements.

The main criteria for sufficient exposure were (1) the identification of a corrosive or otherwise irritant agent in the workplace air, (2) the physicochemical form and air concentration of the agent being capable of entering the patient's lungs and (3) exposure evaluated as clearly and/or repeatedly exceeding a relevant
Table 1 Sources of information used for assessment of exposure of patients with irritant-induced occupational asthma

\begin{tabular}{|c|c|c|c|}
\hline Source of exposure information & $\begin{array}{l}\text { Acute } \\
\mathrm{N}=30 \\
\mathrm{n}(\%)\end{array}$ & $\begin{array}{l}\text { Subacute } \\
\mathrm{N}=39 \\
\mathrm{n}(\%)\end{array}$ & $\begin{array}{l}\text { All } \\
\mathrm{N}=69 \\
\mathrm{n}(\%)\end{array}$ \\
\hline Safety data sheets* & $18(60)$ & $24(62)$ & $42(61)$ \\
\hline Workplace hygiene measurements & $2(7)$ & $24(62)$ & $26(38)$ \\
\hline Patient interview by exposure specialist $\dagger$ & $7(23)$ & $14(36)$ & $21(30)$ \\
\hline $\begin{array}{l}\text { Employer interview by exposure } \\
\text { specialistt }\end{array}$ & $5(17)$ & $15(39)$ & $20(29)$ \\
\hline Accident reports or reports of authorities & $9(30)$ & $2(5)$ & $11(16)$ \\
\hline $\begin{array}{l}\text { Laboratory analyses of workplace } \\
\text { materials } \ddagger\end{array}$ & $2(7)$ & $4(10)$ & $6(9)$ \\
\hline $\begin{array}{l}\text { Personal or stationary online gas } \\
\text { detectors at workplace }\end{array}$ & $3(10)$ & $3(8)$ & $6(9)$ \\
\hline Biomonitoring & $0(0)$ & $4(10)$ & $4(6)$ \\
\hline
\end{tabular}

*In cases with exposure to identified chemical products.

tEither specialised occupational hygienist or occupational toxicologist.

fIncluding emission measurements or analyses of dust samples.

occupational exposure level (OEL). Modifying earlier classifications of respiratory irritants, we grouped the agents according to their chemistry and physical form into acids, bases and their mixtures; inorganic gases; oxidising agents; irritant dusts; other chemicals; other mixtures and endotoxins. ${ }^{15}$

We also determined the single most important root cause of the exposure on the basis of professional views and discussions, and classified them into (1) human error, (2) process or machine failure, (3) neglect of use of personal protective equipment (PPE), (4) neglect of work hygiene measures, (5) lack of information or false instructions and (6) other.

\section{Statistical analysis}

We used SPSS V.26.0 for the data analysis. We expressed continuous variables as means and SD, and categorical values as percentages. We analysed the differences between the groups of acute IIA and subacute IIA using Student's t-test for age, the $\chi^{2}$ test and Fisher's exact test for categorical variables. Due to the small number of cases, the number of subjects in each occupational group was compared with the number of subjects in all other occupational groups. Respectively, the number of subjects having each root cause was compared with the number of subjects having all other root causes. A p $<0.05$ was considered statistically significant.

\section{RESULTS}

We identified 30 patients with acute IIA and 39 with subacute IIA, $84 \%$ of all patients were men and 59\% non-smokers (table 2). The largest occupational group was stationary plant and machine operators, who had significantly more cases of subacute IIA than acute IIA $(p=0.002)$, followed by metal, machinery and related trades workers, and building and related trade workers.

\section{Causative agents and exposure events}

Different types of mixtures caused $26 \%$ of the cases, followed by acid aerosols or fumes (19\%), base aerosols or fumes (13\%), dusts (12\%) and inorganic gases (9\%) (table 3). Forty of the cases $(57 \%)$ were attributable to some type of corrosive acidic or alkaline chemical, also taking into account dusts, gases and different mixtures. A known respiratory sensitiser (hexamethylene diisocyanate, glutaraldehyde or formaldehyde) was a causative agent in only $6 \%$ of the cases. The causatives of acute and subacute IIA 
Table 2 Clinical characteristics and occupations of patients with irritant-induced occupational asthma diagnosed at Finnish Institute of Occupational Health between 2000 and 2018

\begin{tabular}{|c|c|c|c|c|}
\hline Characteristics & $\begin{array}{l}\text { Acute } \\
\mathrm{N}=30\end{array}$ & $\begin{array}{l}\text { Subacute } \\
N=39\end{array}$ & $\begin{array}{l}\text { All } \\
N=69\end{array}$ & $P$ value \\
\hline Age, mean (SD) & $45.1(8)$ & $47.0(12)$ & $46.2(10)$ & 0.436 \\
\hline Men & $25(83)$ & $33(85)$ & $58(84)$ & 0.570 \\
\hline Smoking: & & & & 0.061 \\
\hline Current & $5(17)$ & $9(23)$ & $14(20)$ & \\
\hline Ex & $10(33)$ & $4(10)$ & $14(20)$ & \\
\hline Stationary plant and machine operators & $4(13)$ & $19(49)$ & $23(33)$ & 0.002 \\
\hline Metal, machinery and related trade workers & $7(23)$ & $4(10)$ & $11(16)$ & 0.190 \\
\hline Building and related trade workers (excluding electricians) & $4(13)$ & $4(10)$ & $8(12)$ & 0.720 \\
\hline Drivers and mobile plant operators & $2(7)$ & $3(8)$ & $5(7)$ & 1.000 \\
\hline Science and engineering-associated professions & $2(7)$ & $3(8)$ & $5(7)$ & 1.000 \\
\hline Others $¥$ & $5(17)$ & 1 (3) & $6(9)$ & - \\
\hline
\end{tabular}

The data are presented as numbers (\%), if not otherwise stated. $\mathrm{P}$ values were calculated using independent variables t-test for age, $\chi^{2}$ test for the distribution of smoking status, and Fisher's exact test for other classified variables. Each occupational group was compared with all other occupational groups.

*Classified by International Standard Classification of Occupations on two-digit level. P value is calculated for distribution of occupational classes.

tP values missing due to low number of cases.

$\ddagger$ Only one case per occupation group.

were similar apart from endotoxins, which caused only subacute IIA.

Typical work tasks or exposure events were gassing in pulp mills, different types of repair tasks and leaks in heavy industry, cleaning or washing with corrosive chemicals, transporting of chemicals, accidental fires or other overheating of materials, electroplating and other acid bathing of metals (online supplemental e-Table 1). Sludge handling and working in an animal shed caused exposure to irritants in farming. Two occupational hygienists suffered high-level exposure when performing workplace measurements, as did a police officer and an ambulance worker during rescue tasks. In the food industry, ammonium leaks in cooling systems, hydrogen peroxide used to disinfect lines, and endotoxins in potato flour factory and in handling malt caused asthma. Exposure to cement, calcium oxide or other alkaline dusts was substantial when emptying sacks, in silo breakdowns and when transporting ash.

The identification details, OELs and irritancy-related hazard classifications of the causatives according to current European legislation are presented in online supplemental e-Table 2. Most of the present causatives were classified as skin corrosive.

\section{Workplace measurements}

We used measurements from the patients' own workplaces in 30 cases (table 4, online supplemental e-Table 3). Most of these were related to subacute IIA and had been taken by a trained occupational hygienist. Some companies' own measurements, usually by online gas detectors, were available. The measurements verified exposure levels exceeding the OEL in $10 \%$ of acute and $49 \%$ of subacute IIA cases. In many workplaces, for example, in farms, food processing, mines, metal production, pulp mills and chemical plants, the OEL was exceeded several times. Endotoxin levels were as high as 105 -fold in a piggery, 280 -fold in malt handling in foodstuff production, and 21-fold in a potato flour factory in comparison to, for example, the Dutch OEL. ${ }^{16}$

\section{Root causes}

Lack of information or false guidance was the root cause in $36 \%$ of the acute IIA cases and in $13 \%$ of the subacute IIA cases $(p=0.017)$ (figure $1 \mathrm{~A}, \mathrm{~B})$. Neglect of workplace hygiene measures was the underlying reason in $7 \%$ and $74 \%(\mathrm{p}<0.001)$, and process or machine failure in $27 \%$ and $5 \%$ of the cases $(p=0.016)$, respectively. Neglect of the use of PPE was the root cause in $10 \%$ of all cases.

\section{DISCUSSION}

This is a retrospective descriptive study of 69 patients with IIA, of which 30 had acute IIA and 39 subacute IIA. The diagnostic criteria of IIA included lung function-based verification of asthma and onset of asthma symptoms in a close temporal relationship with exposure to respiratory irritants whose concentrations were estimated to exceed the OEL. The detailed and critical evaluation of the exposure events, causative agents, and their chemical properties, as well as concentrations in the workplaces using many different information sources, was at the core of this study. These factors also make this study novel.

\section{Risk occupations}

The most common occupational groups in our study represented working in production industries that often use large volumes of chemicals. Finnish industry is built on the paper, metal and chemical industry, which naturally affects the high-risk work and causative agents detected in this study. The cases included several mechanics and operators in pulp mills in which many irritants such as hydrogen sulfide, alkaline pulp cooking solutions, oxidising chlorine gases and acidic sulfuric compounds may be present simultaneously. Such work caused both acute and subacute IIA, which may reflect defects in process safety and generally poor air quality. Repeated gassing episodes involving 
Table 3 Causative agents of irritant-induced asthma

\begin{tabular}{|c|c|c|c|}
\hline Main groups of causative agents & $\begin{array}{l}\text { Acute } \\
\mathrm{N}=30\end{array}$ & $\begin{array}{l}\text { Subacute } \\
\mathrm{N}=39\end{array}$ & $\begin{array}{l}\text { Total } \\
\mathrm{N}=69(\%)\end{array}$ \\
\hline Acid aerosols or fumes & $\begin{array}{l}6 \\
\text { Sulfuric acid } \\
\text { Hydrofluoric acid } \\
\text { Nitric acid } \\
\text { Hydrochloric acid } \\
\text { Hydrochloric acid and sulfur dioxide }\end{array}$ & $\begin{array}{l}7 \\
\text { Sulfuric acid* and ammonium fluoride } \\
\text { Sulfuric acid* and hydrogen sulfide } \\
\text { Sulfuric acid*, sulfur dioxide and sulfur trioxide } \\
\text { Hydrochloric acid } \\
\text { Nitric acid }\end{array}$ & $13(19)$ \\
\hline Base aerosols or fumes & $\begin{array}{l}5 \\
\text { Ammonia } \\
\text { Sodium hydroxide } \\
\text { Black lye }\end{array}$ & $\begin{array}{l}4 \\
\text { Ammonia } \\
\text { Sodium hydroxide } \\
\text { Alkaline epoxy polyamine hardener and cleaning agent }\end{array}$ & $9(13)$ \\
\hline Mixtures of acid and base aerosols or fumes & & $\begin{array}{l}3 \\
\text { Ammonia, sulfuric acid, hydrochloric acid, hydrofluoric } \\
\text { acid, nitric acid } \\
\text { Sodium hydroxide, potassium hydroxide, sulfuric acid, } \\
\text { nitric acid }\end{array}$ & $3(4)$ \\
\hline Inorganic gases & $\begin{array}{l}3 \\
\text { Chlorine dioxide }\end{array}$ & $\begin{array}{l}3 \\
\text { Chlorine dioxide } \\
\text { Chlorine dioxide and hydrogen sulfide } \\
\text { Sulfur dioxide }\end{array}$ & $6(9)$ \\
\hline Oxidising agents & $\begin{array}{l}1 \\
\text { Ozone }\end{array}$ & $\begin{array}{l}1 \\
\text { Hydrogen peroxide }\end{array}$ & $2(3)$ \\
\hline Other chemicals & $\begin{array}{l}5 \\
\text { Formaldehydet } \\
\text { Glutaraldehyde } \dagger \\
\text { Hexamethylene diisocyanate† } \\
\text { Naphthalene compounds } \\
\text { Pyrethrin }\end{array}$ & $\begin{array}{l}1 \\
\text { Hexamethylene diisocyanatet }\end{array}$ & $6(9)$ \\
\hline Mixtures & $\begin{array}{l}6 \\
\text { Bitumen, solvents and their thermal } \\
\text { degradation products } \\
\text { Sodium hydroxide, sodium hypochlorite } \\
\text { Combustion gas } \\
\text { Thermal degradation of polyester paint } \\
\text { Sulfuric acid, sodium hypochlorite, } \\
\text { chlorine dioxide gas } \\
\text { Nitric oxides, diesel exhaust, mixture of } \\
\text { oil and water }\end{array}$ & $\begin{array}{l}12 \\
\text { Ammonia and hydrogen sulfide } \\
\text { Ammonia, hydrogen sulfide and endotoxins } \\
\text { Hydrogen sulfide, sulfur compounds, sodium hydroxide, } \\
\text { chlorine dioxide } \\
\text { Calcium oxide and hydrogen sulfide } \\
\text { Rubber chemicals and their thermal degradation products } \\
\text { Solvents and mine dust } \\
\text { Formic acid, acetic acid, formaldehyde } \\
\text { Thermal degradation of polyvinyl chloride-polyurethane } \\
\text { fabrics } \\
\text { Trifluoroacetic acid and acetonitrile }\end{array}$ & $18(26)$ \\
\hline Dusts & $\begin{array}{l}4 \\
\text { Calcium oxide } \\
\text { Cement }\end{array}$ & $\begin{array}{l}4 \\
\text { Ash } \\
\text { Calcium oxide and alkaline dusts } \\
\text { Cement } \\
\text { Sulfuric acid-containing titanium oxide powder }\end{array}$ & $8(12)$ \\
\hline Endotoxins & 0 & 4 & $4(6)$ \\
\hline
\end{tabular}

${ }^{*}$ Main causative agent.

tSensitiser-induced occupational asthma was considered to be unlikely based on the results of specific inhalation test or the anamnesis.

sulfur dioxide and other irritants in pulp mills have previously been connected to asthma onset. ${ }^{1718}$

Other work tasks in our study entailed the handling of acids and alkali in mines and metal plants in processes such as smelting and electrolysis, and in the pretreatment of metals. Several of the cases were in the transport sector, in tasks involving loading and unloading irritant materials. This indicates defects in control measures and knowledge on chemical hazards. In construction work, floor surfacing, the cleaning of concrete elements and the handling of cement led to asthma onset. One key risk trade was agriculture, specifically animal husbandry. In sheds and sludge units, ammonia and hydrogen sulfide originate from animal faeces, which may hamper the identification of exposure, although toxic gases have been reported to cause asthma in piggeries. ${ }^{19}$
Previously, long-term exposure to ammonia or dust in piggeries has shown to increase bronchial hyper-responsiveness. ${ }^{19} 20$

Earlier data on the risk occupations of IIA is limited. In a study of 123 workers with IIA in the USA, the most common occupations were (1) precision production, (2) craft and repair and (3) technical, sales and administrative support. ${ }^{21}$ It is difficult to compare this study with ours due to its different classification of occupations and lack of clinical verification of asthma. Epidemiological surveys have identified a high risk of asthma in occupations partly similar to those in our study, for example, metal work and stationary engine and machine work, construction work $^{22}$ and farming. ${ }^{23-25}$ Our series included only two cleaners, but several studies have detected an increased asthma risk in cleaning work. ${ }^{122326}$ This may indicate that cleaning work in 
Table 4 Workplace measurements when available and relevant for assessment of exposure to irritant factors

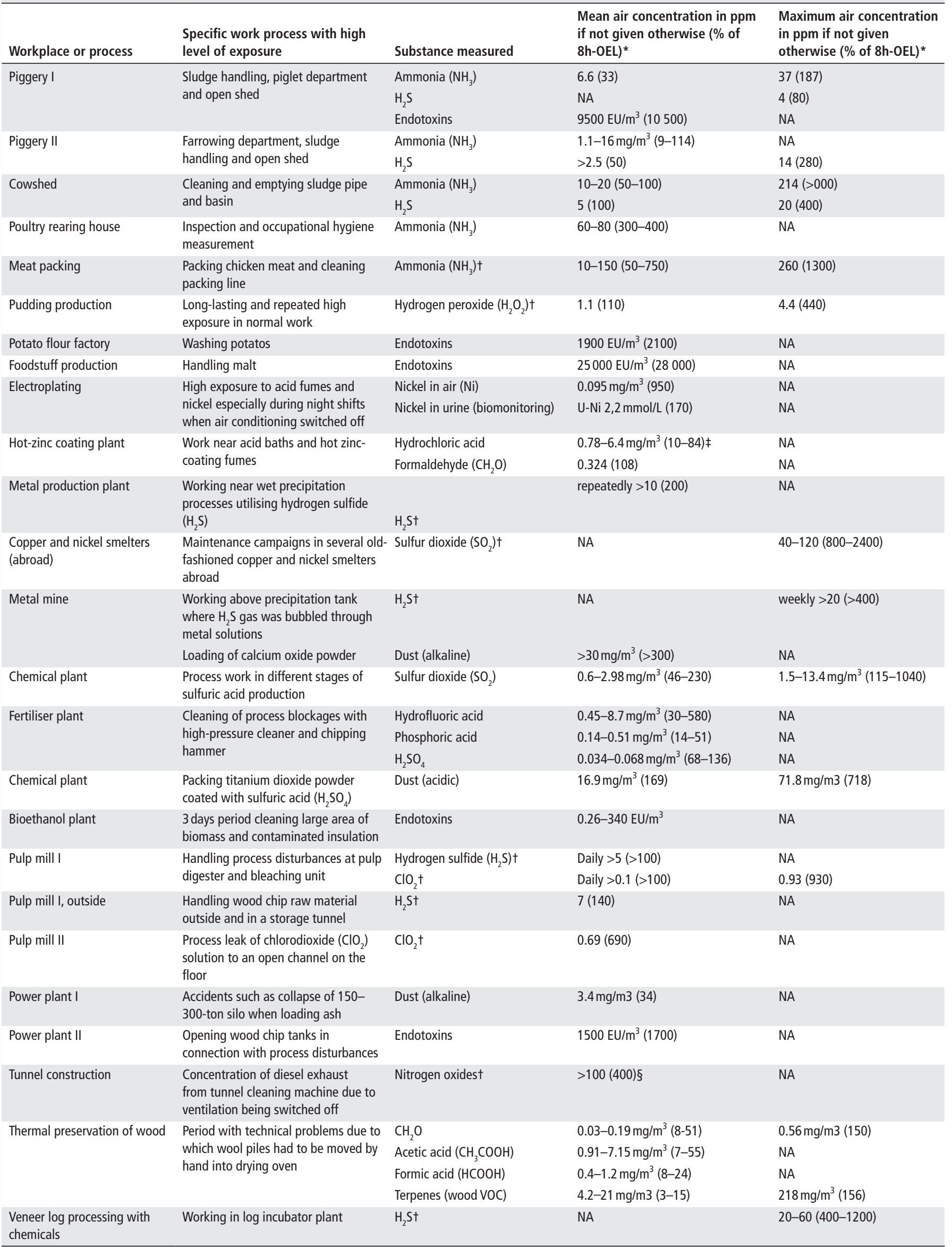


Table 4 continued

\begin{tabular}{|c|c|c|c|c|}
\hline Workplace or process & $\begin{array}{l}\text { Specific work process with high } \\
\text { level of exposure }\end{array}$ & Substance measured & $\begin{array}{l}\text { Mean air concentration in ppm } \\
\text { if not given otherwise (\% of } \\
8 \mathrm{~h}-\mathrm{OEL})^{*}\end{array}$ & $\begin{array}{l}\text { Maximum air concentration } \\
\text { in ppm if not given } \\
\text { otherwise (\% of } 8 \mathrm{~h}-\mathrm{OEL})^{*}\end{array}$ \\
\hline Processing PVC- fabrics & $\begin{array}{l}\text { Heat seaming of large PVC- } \\
\text { impregnated fabrics, air conditioning } \\
\text { problems }\end{array}$ & Total VOC & $3-5 \mathrm{mg} / \mathrm{m}^{3}$ & $6.5 \mathrm{mg} / \mathrm{m}^{3}$ \\
\hline
\end{tabular}

Some measurements conducted by trained occupational hygienist and some by respective company's own follow-up.

${ }^{*}$ Finnish OEL and if not set, other relevant European OEL.

tMeasurements company's own follow-up by online gas detectors etc.

¥Only short-term (15 min) OEL set.

$\S$ Company-defined exposure limit for total oxides of nitrogen was $25 \mathrm{mg} / \mathrm{m}^{3}$.

EU, endotoxin unit; NA, not available; OEL, occupational exposure limit; PVC, polyvinyl chloride; VOC, volatile organic compounds.

Finland involves long-term exposure to low levels of irritants, which means that it does not meet the criteria of IIA.

\section{Exposure events and causative agents}

The exposure events varied, and therefore the thorough description of our cases and exposures in online supplemental e-tables 1 and 3 may help clinicians identify IIA. The most frequently involved agents causing IIA were corrosive inorganic acids and bases (alkali), representing more than half of the cases. Sulfuric acid was the most common unique causative in both acute and subacute IIA. Many of the dust exposures or mixtures in this series were also strongly acidic or alkaline, making classifications of causative agents difficult. Identifying a dust's chemical nature, such as its $\mathrm{pH}$, is essential, when evaluating its potential to cause IIA. An inert dust, for example, titanium dioxide, can be corrosive if covered with sulfuric acid. Alkaline dust (eg, cement or calcium oxide), whose role as an IIA causing agent has increased after the World Trade Center tragedy, was a causative agent in $10 \%$ of our patients. ${ }^{27}$ Isocyanates caused IIA in only two cases in which the high-level exposure to isocyanates had occurred through burning polyurethane insulation material and malfunctioning PPE in spray painting and sensitisation was ruled out. Strong acids, especially sulfuric acid, have been reported to be fairly common causes of IIA,,$^{28}$ but chlorine, ${ }^{8} 10111328-30$ sulfur dioxide, ${ }^{101329}$ isocyanates, ${ }^{5} 101113$ ammonia, cleaning agents ${ }^{10}$ and oxides of nitrogen ${ }^{11}$ have been the most common. Due to its detailed exposure assessment, we are quite confident that the present study's causatives were identified correctly.

We evaluated that endotoxins caused asthma in four cases. Extremely high concentrations of endotoxins were measured in the piggery, the power plant using wood chips, the foodstuff

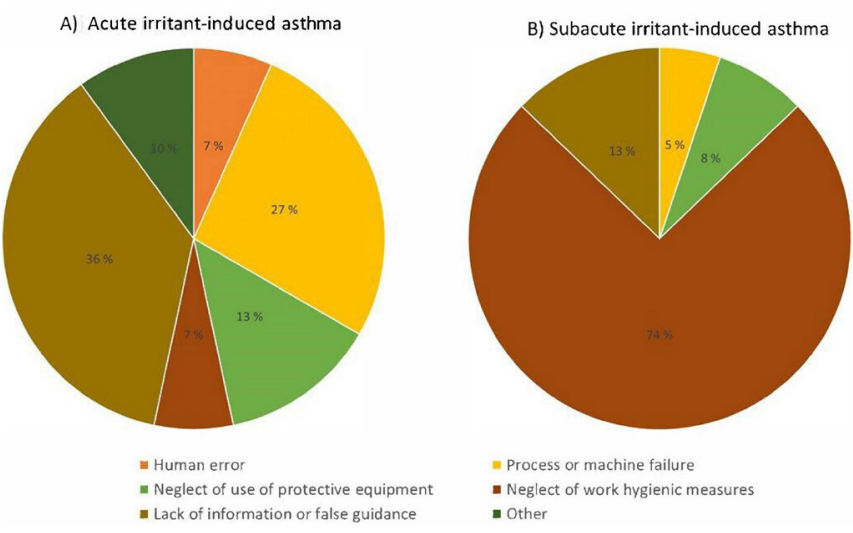

Figure 1 The root causes of acute $(A)$ and subacute $(B)$ irritant-induced asthma. production, and the potato flour factory, which is in line with an earlier report on endotoxin exposure in livestock farming. ${ }^{31}$ We are not aware of previous reports on endotoxin-related IIA, but a decline in lung function across the work shift among fibreglass workers, an increase in bronchial hyper-reactivity among farmers, and greater loss in lung function among cotton workers has shown to be associated with endotoxin exposure. ${ }^{32-34}$

\section{Identification of irritants and their OELs}

According to the classification, labelling and packaging regulation of the European Union, a chemical's irritancy is most often determined via its effect on the skin. ${ }^{35}$ The most potent airway irritants such as inorganic acids and alkali reported here are classified as corrosive ('Skin Corr 1A' or 'Skin Corr 1B'), defined as irreversible tissue damage on the skin in $<3-60 \mathrm{~min}$. In addition to these classifications, the chemical's SDS contains the hazard statement EUH314 'Causes severe skin burns and eye damage' and in some cases also EUH071: 'Corrosive to the respiratory tract'. Another mechanism through which chemicals can cause tissue damage in airways is oxidation; chemicals with such potential are classified in the SDS as oxidative ('Ox Gas' or 'Ox Liq'). Most IIA-causing chemicals' OELs are based on their irritancy. Thus, we advise consulting the relevant OELs when assessing exposure for IIA.

\section{Workplace measurements}

Workplace measurements were useful, especially in the subacute IIA cases, as exceeding the OEL was verified in half of these cases. In several workplaces, extremely high concentrations of irritants, even exceeding the OEL by manifold, were measured (table 4). Quantitative measurements in pulp and paper mills are scarce, possibly due to the fact that companies' own follow-up data are seldom published. ${ }^{36}$ Bråtveit et al reported high exposure to acids in electroplating ${ }^{37}$ and Haddam et al to sulfur dioxide in smelters. ${ }^{38}$ As regards animal facilities, high occupational exposure to ammonia and hydrogen sulfide has been discovered in, for example, swine and poultry sheds. ${ }^{3940}$ Surprisingly, many of the present patients' employers have not taken preventive measures, despite these worrying findings. The lack of workplace measurements other than online gas detector data is natural in acute cases, as these events are unexpected. Heavy exposure of the two occupational hygienists in present series suggested poor preparation for their core task.

\section{Root causes}

The main root cause of acute IIA was found to be lack of information or false guidance, which stresses the need to identify risk chemicals and guide employees in matters related to them at 
workplaces. Guidance should include lifesaving first aid procedures. Earlier analyses of chemical accidents have identified equipment failure, human error, lack of effective PPE or other contraventions of safety regulations as leading causes..$^{29}{ }^{41}$ The neglect of work hygiene measures was found to be the most important background reason for subacute IIA. In these cases, air quality was often clearly deficient, and important, general control measures were not routinely applied. As regards PPE defects, we observed cases with no PPE at all, but also cases in which PPE was unsuitable, broken or used incorrectly. There are often several reasons for high-level exposure and identification of a single most important root cause based on medical records is quite demanding. The risk of misclassification was, however, reduced by the generous amount of data, extended evaluation of exposure events (table 1) and multidisciplinary discussions.

\section{Subacute IIA}

Subacute IIA is a controversial diagnosis due to little medical evidence and difficulties in separating this type of IIA from asthma related to low dose exposure to irritants. ${ }^{5}{ }^{6}$ Brooks described 25 cases of subacute IIA, but only 15 had new-onset asthma. We report 39 cases with subacute IIA. The evidence of exposure to respiratory irritants exceeding the OELs convinced us that the cases really had subacute IIA rather than low-dose exposure IIA. For half of the cases we had measurement data on high-level exposure from the patients' workplace and for the rest of the cases we had other information strongly indicating this (eg, high volumes of irritants in confined spaces or repeated process failures with visible gas or aerosols). Some reports have suggested a maximum length of exposure time for subacute IIA, but we did not apply limits to the length of exposure. ${ }^{5} 10$ The causative agents of subacute IIA were similar to those of acute IIA, but otherwise we found many differences between the groups. The patients with acute IIA represented varied occupational groups, whereas half of the cases with subacute IIA worked as stationary plant and machine operators in metal processing, mines, pulp mills, power plants or in the chemical, plastic or food industry. This reflects neglect of work hygiene measures in many sectors of heavy industry, which was also the main root cause of subacute IIA. It is noteworthy that in many cases of subacute IIA, employees had been exposed to high levels of irritants when performing their normal work tasks, and not during exceptional situations.

\section{CONCLUSIONS}

Based on this large case series of clinically verified IIA, physicians should suspect IIA among patients with asthma onset after highlevel exposure to airborne agents with corrosive or oxidising properties, for example, strong acids or bases. Acute IIA is typical after chemical accidents or other hazardous events, but subacute IIA can develop in risk trades in employees' normal work tasks if work hygiene measures are poor. Production and maintenance workers in the metal, paper, chemical and food industry, miners, farmers, transport workers and construction workers seem to be especially at risk of IIA. Control measures for clearly hazardous chemicals may be deficient even in a country considered to have good workplace hygiene standards.

Lack of information and false guidance on chemical hazards and neglect in elementary hygiene measures in cases of repeated exposure seem to be important underlying reasons for IIA. This suggests that increasing chemical risk knowledge and control by educating health safety authorities, employees, employers and occupational health services plays a key role in the prevention of IIA and other irritant-induced respiratory complaints.

Acknowledgements We thank The Finnish Work Environment Fund for supporting the study.

Contributors IL had full access to all the data and takes responsibility for the integrity of the data and the accuracy of the data analysis. IL, JL, KK, SS, KY, HS and KS contributed substantially to the study design, data collection, analysis and interpretation, and the writing of the manuscript.

Funding The Finnish Work Environment Fund supported the study (grant number 190390).

Competing interests None declared.

Patient consent for publication Not required.

Ethics approval The study was approved by the ethics committee of Helsinki University Central Hospital (approval number HUS/611/2020). According to the local legislations and ethical committees, no approval was needed because no patient intervention was involved at the $\mathrm{FIOH}$.

Provenance and peer review Not commissioned; externally peer reviewed.

Data availability statement No data are available. The data are archived in the repository of Finnish Institute of Occupational Health.

Supplemental material This content has been supplied by the author(s). It has not been vetted by BMJ Publishing Group Limited (BMJ) and may not have been peer-reviewed. Any opinions or recommendations discussed are solely those of the author(s) and are not endorsed by BMJ. BMJ disclaims all liability and responsibility arising from any reliance placed on the content. Where the content includes any translated material, BMJ does not warrant the accuracy and reliability of the translations (including but not limited to local regulations, clinical guidelines, terminology, drug names and drug dosages), and is not responsible for any error and/or omissions arising from translation and adaptation or otherwise.

Open access This is an open access article distributed in accordance with the Creative Commons Attribution Non Commercial (CC BY-NC 4.0) license, which permits others to distribute, remix, adapt, build upon this work non-commercially, and license their derivative works on different terms, provided the original work is properly cited, appropriate credit is given, any changes made indicated, and the use is non-commercial. See: http://creativecommons.org/licenses/by-nc/4.0/.

\section{ORCID iD}

Irmeli Lindström http://orcid.org/0000-0002-6399-8846

\section{REFERENCES}

1 Lillienberg L, Andersson E, Janson C, et al. Occupational exposure and new-onset asthma in a population-based study in northern Europe (Rhine). Ann Occup Hyg 2013:57:482-92.

2 Kogevinas M, Zock J-P, Jarvis D, et al. Exposure to substances in the workplace and new-onset asthma: an international prospective population-based study (ECRHS-II). Lancet 2007;370:336-41.

3 Brooks SM, Weiss MA, Bernstein IL. Reactive airways dysfunction syndrome (rads). persistent asthma syndrome after high level irritant exposures. Chest 1985;88:376-84

4 Tarlo SM, Broder I. Irritant-induced occupational asthma. Chest 1989;96:297-300.

5 Brooks SM, Hammad Y, Richards I, et al. The spectrum of irritant-induced asthma: sudden and not-so-sudden onset and the role of allergy. Chest 1998;113:42-9.

6 Vandenplas 0, Wiszniewska M, Raulf M, et al. EAACl position paper: irritant-induced asthma. Allergy 2014;69:1141-53.

7 Gautrin D, Boulet LP, Boutet $M$, et al. Is reactive airways dysfunction syndrome a variant of occupational asthma? J Allergy Clin Immunol 1994;93:12-22.

8 Malo J-L, L'archevêque J, Castellanos L, et al. Long-Term outcomes of acute irritantinduced asthma. Am J Respir Crit Care Med 2009;179:923-8.

9 Dumas O, Laurent E, Bousquet J, et al. Occupational irritants and asthma: an Estonian cross-sectional study of 34,000 adults. Eur Respir J 2014:44:647-56.

10 Baur X, Bakehe P, Vellguth $\mathrm{H}$. Bronchial asthma and COPD due to irritants in the workplace - an evidence-based approach. J Occup Med Toxicol 2012;7:19.

11 Shakeri MS, Dick FD, Ayres JG. Which agents cause reactive airways dysfunction syndrome (rads)? A systematic review. Occup Med 2008;58:205-11.

12 Takeda N, Maghni K, Daigle S, et al. Long-term pathologic consequences of acute irritant-induced asthma. J Allergy Clin Immunol 2009;124:975-81.

13 Ross DJ, McDonald JC. Asthma following inhalation accidents reported to the sword project. surveillance of work-related and occupational respiratory disease. Ann Occup Hyg 1996;40:645-50.

14 (ILO) ILO. International standard classification of occupations 2008, 2008. 
15 Vandeplaas OSH. Work-Related Asthma: Occupational Asthma and Work. Exacerbated Disease. In: Newman Taylor AJ, Cullinan P, Blanc P, et al, eds. Occupational lung disorders. Taylor\&Francis Group, 2017: 343.

16 Netherlands THHCot. Endotoxins. Health-based recommended occupational exposure limit, 2010.

17 Chang-Yeung M, Lam S, Kennedy SM, et al. Persistent asthma after repeated exposure to high concentrations of gases in pulpmills. Am J Respir Crit Care Med 1994;149:1676-80.

18 Andersson E, Knutsson A, Hagberg S, et al. Incidence of asthma among workers exposed to sulphur dioxide and other irritant gases. Eur Respir J 2006;27:720-5.

19 Cormier Y, Coll B, Laviolette M, et al. Reactive airways dysfunction syndrome (RADS) following exposure to toxic gases of a swine confinement building. Eur Respir J 1996:9:1090-1.

20 Vogelzang PF, van der Gulden JW, Folgering $\mathrm{H}$, et al. Longitudinal changes in bronchial responsiveness associated with swine confinement dust exposure. Chest 2000;117:1488-95.

21 Henneberger PK, Derk SJ, Davis L, et al. Work-related reactive airways dysfunction syndrome cases from surveillance in selected US states. J Occup Environ Med 2003;45:360-8

22 Karjalainen A, Kurppa K, Martikainen R, et al. Work is related to a substantial portion of adult-onset asthma incidence in the Finnish population. Am J Respir Crit Care Med 2001;164:565-8.

23 Eng A, 'T Mannetje A, Douwes J, et al. The New Zealand workforce survey II: occupational risk factors for asthma. Ann Occup Hyg 2010;54:154-64.

24 Karjalainen A, Kurppa K, Virtanen S, et al. Incidence of occupational asthma by occupation and industry in Finland. Am J Ind Med 2000:37:451-8.

25 Omland Øyvind, Hjort C, Pedersen OF, et al. New-onset asthma and the effect of environment and occupation among farming and nonfarming rural subjects. J Allergy Clin Immunol 2011;128:761-5.

26 Svanes Øistein, Bertelsen RJ, Lygre SHL, et al. Cleaning at home and at work in relation to lung function decline and airway obstruction. Am J Respir Crit Care Med 2018; 197:1157-63.

27 Wisnivesky JP, Teitelbaum SL, Todd AC, et al. Persistence of multiple illnesses in World Trade Center rescue and recovery workers: a cohort study. Lancet 2011:378:888-97.
28 Tarlo SM, Liss G, Corey P, et al. A workers' compensation claim population for occupational asthma. Comparison of subgroups. Chest 1995; 107:634-41.

29 Sallie B, McDonald C. Inhalation accidents reported to the SWORD surveillance project 1990-1993. Ann Occup Hyg 1996;40:211-21.

30 Lemière $C$, Malo JL, Boutet M. Reactive airways dysfunction syndrome due to chlorine: sequential bronchial biopsies and functional assessment. Eur Respir J 1997:10:241-4.

31 Basinas I, Sigsgaard T, Kromhout $\mathrm{H}$, et al. A comprehensive review of levels and determinants of personal exposure to dust and endotoxin in livestock farming. $J$ Expo Sci Environ Epidemiol 2015;25:123-37.

32 Milton DK, Wypij D, Kriebel D, et al. Endotoxin exposure-response in a fiberglass manufacturing facility. Am J Ind Med 1996;29:3-13.

33 Smit LAM, Heederik D, Doekes G, et al. Occupational endotoxin exposure reduces the risk of atopic sensitization but increases the risk of bronchial hyperresponsiveness. Int Arch Allergy Immunol 2010;152:151-8.

34 Wang X-R, Zhang H-X, Sun B-X, et al. A 20-year follow-up study on chronic respiratory effects of exposure to cotton dust. Eur Respir J 2005;26:881-6.

35 ECHA. Guidance to regulation (EC) No 272/2008 on classification, labelling and packaging (CLP) of substances and mixtures. Version 5.0, 2017: 275-6. https://echa. europa.eu/documents/10162/23036412/clp en.pdf/58b5dc6d-ac2a-4910-9702e9e1f5051cc5

36 Teschke K, Ahrens W, Andersen A, et al. Occupational exposure to chemical and biological agents in the nonproduction departments of pulp, paper, and paper product Mills: an international study. Am Ind Hyg Assoc J 1999;60:73-83.

37 Bråtveit M, Haaland IM, Moen BE, et al. Exposure to sulfuric acid in zinc production. Ann Occup Hyg 2004;48:159-70.

38 Haddam N, Samira S, Dumont X, et al. Lung epithelium injury biomarkers in workers exposed to sulphur dioxide in a non-ferrous smelter. Biomarkers 2009;14:292-8.

39 Park J, Kang T, Heo Y, et al. Evaluation of short-term exposure levels on ammonia and hydrogen sulfide during Manure-Handling processes at livestock farms. Saf Health Work 2020;11:109-17.

40 Whyte RT. Occupational exposure of poultry stockmen in current barn systems for egg production in the United Kingdom. Br Poult Sci 2002;43:364-73.

41 Welles WL, Wilburn RE, Ehrlich JK, et al. New York hazardous substances emergency events surveillance: learning from hazardous substances releases to improve safety. $J$ Hazard Mater 2004:115:39-49. 